\title{
The venture capital contract and the Institutional Theory in a Spanish setting
}

\author{
Ma Camino Ramón-Llorens, Ginés Hernández-Cánovas \\ Universidad Politécnica de Cartagena (Spain) \\ camino.ramon@upct.es,gines.hernandez@upct.es
}

Received: December 2012

Accepted: March 2013

\section{Abstract}

Purpose: This paper examines the principles of the Institutional Theory in order to increase the understanding of the contractual covenants that Spanish venture capital firms use in their relationship with the portfolio companies.

Design/methodology/approach: The study is based on the data obtained by means of a postal survey addressed to the 70 Spanish venture capital firms registered in the ASCRI (Asociación Española de Entidades de Capital Riesgo) in June, 2002, with a response rate of $68.33 \%$. As a theoretical framework we base on the Institutional Theory as a mechanism to understand the venture capital contractual process.

Findings: The results show that a large part of the Spanish venture capital contracts are homogeneous. However, between public and private venture capital firms there is some heterogeneity not only in relation to the industry but also within the field in the design of contracts. It might be due to the coercive pressures exerted by the government on public entities.

Research Limitations: Although survey data might create potential biases and possible measurement problems, we consider that our sample has large enough coverage of the venture capital industry (68.33\%) that, although cautiously, valid conclusions can be drawn.

Originality/value: To the best of our knowledge, this study is one of the first empirical contributions analyzing financial contracts of venture capital firms in Spain. A better understanding of covenants included in venture capital contracts can help Spanish firms to understand the particular terms and restraints of venture capitalists before providing 
capital. Moreover, this paper also has clear benefits for policy makers and venture capitalists.

Keywords: Venture capital contract, Institutional Theory

JEL Codes: G24

\section{Introduction}

The work of Suchman (1995) proposes the Institutional Theory as a mechanism to understand the venture capital contractual process, based on the idea that social and cultural pressures become established as a rule for social behaviour. The Institutional Theory states that organizations and their strategies are influenced by the institutional settings in which they operate, and shaped by the institutional legacies which reflect the culture, history, and polity of the particular country or region (Doh \& Guay, 2006), making organizations homogenous over time (DiMaggio \& Powell, 1983).

DiMaggio and Powell (1983) call this tendency toward homogeneity "isomorphism", identifying three isomorphic forces: coercive, mimetic and normative. As a consequence of these forces in the industry, one might expect the behaviour of the venture capitalists (VCs) as a whole to be quite homogeneous when choosing the covenants that will regulate their relations with the companies they invest in (Jog, Lawson \& Riding, 1991 in Canada; and Isaksson, Cornelius, Landström \& Junghagen, 2004 in Sweden). For example, less experienced venture capitalists will copy the covenants included by their more experienced counterparts in the industry (Isaksson et al., 2004). It is also possible that some organizational fields within the industry are more homogeneous than others, originating differences in the use of covenants between fields. Empirical evidence provided by Isaksson et al. (2004) shows the existence of differences in the use of covenants between public and private venture capital firms (VCF), or between early and later stage investors. Due to this heterogeneity, the same business proposal might obtain different treatment depending on the venture capitalists that the entrepreneur approaches. This creates uncertainty and could discourage entrepreneurs from applying for venture financing.

Following the above theory and the existing evidence, the objective of this paper is twofold. Firstly, we analyze whether Spanish venture capitalists in our sample are homogeneous as a whole when writing their contracts with the investee company. Our results show that Spanish venture capital firms in our sample are quite homogeneous. There are not covenants hardly used by a high number of venture capitalists and $36 \%$ of the covenants are almost always included in their contracts by more than $80 \%$ of the companies. However, some degree of heterogeneity in the industry as a whole arises because $64 \%$ of covenants are only used by 
venture capitalists for specific situations and purposes. The second objective consists of checking whether there are some organizational fields that are more isomorphic than others. We find the existence of differences in the design of contracts between public and private venture capital firms that, contrary to our expectations, arise due to a lower degree of isomorphism within the group of public companies. It seems that coercive pressures exerted by the government on public entities make their behavior heterogeneous not only in relation to the industry but also within the field.

We carry out our analyses using a survey dataset of 41 Spanish venture capital firms providing information regarding contractual arrangements used in their relationship with their portfolio companies. We think that our sample perfectly suits our objective due to the important expansion that the Spanish venture capital sector has experienced since the end the twentieth century. Venture capital finance has been central in promoting the development of new technologies, job creation, economic growth and the regional development, which help to develop and consolidate a new category of entrepreneurs, who are more innovate, better trained and more dynamic. It should be also highlighted the significant financing gap of Spanish small and medium-sized firms (SMEs), which makes the venture capital sector one of the main players to many SMEs that are rapidly growing or that are developing high risk products (Del Palacio, Zhang \& Sole, 2012). In fact, the Spanish VC sector is basically focused on SMEs, helping them to grow faster, create more jobs, and invest more forcibly than nonfinanced firms in the sector.

Our paper yields two specific contributions. First, up to the best of our knowledge this is the first paper analyzing the association between venture capital contracts and the Institutional Theory in Spain. And second, our findings uncover the existence of unexpected heterogeneity in the venture capital industry within the field of public own organizations. Further research on this topic will show whether this heterogeneity is the result of greater flexibility or discretionary behaviour from public venture capitalists.

The paper proceeds as follows. Section 2 discusses previous research. Section 3 presents the data and method. Section 4 presents the results, and section 5 concludes.

\section{The Institutional Theory}

According to Bruton, Fried and Manigart (2005), VCs are subject to different institutional forces which can influence their behaviour. These institutional forces are studied by the Institutional Theory, which considers the process by which organizations adapt to the social and cultural pressures of the institutional environment in order to achieve legitimacy, become established as a rule for social behaviour and make organizations homogenous over time. DiMaggio and Powell (1983) call this tendency toward homogeneity "isomorphism", which occurs when 
organizations seek cultural and political legitimacy. The institutional isomorphism takes place through three types of mechanisms defined by DiMaggio and Powell (1983): (1) coercive isomorphism is an exogenous force arising from political pressures and the need for legitimacy, (2) normative isomorphism is an endogenous force that stems from the influence of the professionalization and the role of education, and (3) mimetic isomorphism is an endogenous force resulting from circumstances of uncertainty.

DiMaggio and Powell (1983) claim that the three institutional mechanisms create and diffuse a common set of values, norms, and rules to produce similar practices and structures across organizations that share a common organizational field. Organizational field is defined by DiMaggio and Powell (1983) as "those organizations which, in the aggregate, constitute a recognized area of institutional life: key suppliers, resources and product consumers, regulatory agencies, and other organizations that produce similar services or products". Throughout institutionalization these rules are embedded within an industry or the society as a whole and become a guide for people and firms, reducing uncertainty and providing stable structures for human interaction (North, 1990). Institutions are defined as norms, or behavioral traits that guide human conduct explaining what is and is not, what can be acted upon and what cannot (Hoffman, 1999). North (1990) differentiates between formal and informal institutions. Formal institutions are laws and regulations usually supported by coercive forces. Whereas informal institutions include taboos, norms, conventions, traditions and codes of conduct supported by mimetic and normative pillars.

The coercive dimension of the Institutional Theory is the most formal institution, and refers to exogenous pressures exerted on one organization by another in which the first one is dependent (DiMaggio \& Powell, 1983; Scott, 1995). This regulatory dimension of the Institutional Theory is driven by the provisions of government legislation (North, 1990), as well as industrial agreements and standards (Bruton, Ahlstrom \& Han-Lin, 2010), that control the behavior of firms (North, 1990). In VC context, government action or state intervention play an important role in the development of institutional legitimacy by exerting pressure through their control of funding, or by the exercise of their power to regulate (Frumkin \& Gelaskiewicz, 2004; Cornelius, 2005). Public venture capitalists as perceived by policy makers have goals similar to their own (Cornelius, 2005), such as the promotion of a region's economic growth or small firm's growth rather than obtaining a high profitability (Jeng \& Wells, 2000; Cumming \& MacIntosh, 2006; Brander, Egan \& Hellmann, 2009; Munari \& Toschi, 2010). As a consequence, coercive isomorphism should be stronger in the organizational field of public venture capital firms, resulting in differences in the use of covenants between public and private VC firms.

The normative elements of institutions are the expected behavior of individuals and organizations which are propagated through teaching and training (DiMaggio, 2001). Normative isomorphism is usually associated with the pressures arising from the role of 
professionalization, which leads to similar forms in a particular organizational field. DiMaggio and Powell (1983) emphasize that professionalization is the collective effort of members of an organization in order to define the conditions and methods of their work. In VC context, venture capitalists are trained in the same educational context and share similar cultural and economic background as well as norms regarding the appropriate way of working in the profession. Therefore, the normative pressures derived from VCs' professionalization drives the contractual behaviour towards standardization.

Cultural-cognitive institutions represent informal taken for granted rules and common shared beliefs that are established among individuals through social interactions (Scott, 1995). These culture/cognitive institutions were called mimetic isomorphism by DiMaggio and Powell (1983), which arise in response to environments of great uncertainty and involve the imitation of the behaviour, structures and practices of more successful or more legitimate organizations, in order to increase their chances for survival. Since VCs-entrepreneur relationship is characterized by risk and uncertainty (Tykvová, 2007), the most successful VC firms will be imitated by the less successful ones, driving the VC contracting behavior toward standardization.

Empirical evidence regarding the development of Institutional Theory as an instrument to understand the financial contracts in the venture capital industry is scarce. Suchman (1995) examines 108 financial contracts from two important venture capital funds in California's Silicon Valley, during the period 1975-1990. They find that venture capital contracts become standardized over time due to normative isomorphism and that standardization declines with geographical distance from Silicon Valley. Later, in Sweden, the Institutional Theory supports the results provided by Isaksson et al. (2004). They find some differences between public and non-public venture capital firms that may result from the political pressures on public organizations. Private venture capitalists turn towards standardized covenants, whereas the public ones leant towards situational elements. Their results do not show many differences between the contractual choices made by more or less experienced venture capitalists. Finally, they find that early and late stage investors are two different organizational cultures controlling the design of contracts in these groups.

\section{Data and methodology}

In this section we present the data and methodology we use in our analyses to study the influence that the institutional forces might have on the standardization of venture capital contracts.

\section{Data}

The Spanish venture capital industry grew significantly until 2000, in terms of both capital available for investment and the number of Spanish firms participating in the market. However, 
it was at this point when the crisis arrived to the technological market, that the European sector in general and the Spanish one in particular suffered its consequences. This meant the end of the continued growth in investment activity, which fell from 1,320 million Euro in 2000 to 972 million Euro in 2002 (Data provided by the Spanish association of venture capital, ASCRI).

We obtain the data by means of a postal survey addressed to the 70 Spanish VCF registered in ASCRI in June, 2002. The design of the questionnaires received valuable contributions provided by prestigious economists specialized in financial risk assessment and particularly related with the valuation of ventures. Before sending out the questionnaire, we contacted the 70 VCF to check their willingness to participate in the survey and identify the person in charge of taking the funding decision. Three of the companies were reluctant to answer the surveys, one was unreachable, and six had not made venture capital operations in recent years. From the 60 postal questionnaires that finally were sent, 41 questionnaires were received until February 2003, which corresponds to a response rate of $68.33 \%$.

In table 1 we display some descriptive statistics of VC firms in our sample. We observe that the average VCF is 9.54 years old, has almost 11 employees, made investments and has 20 companies in its portfolio. Table 1 also shows the heterogeneity of our sample, where the age of the firms ranges from 1 to 21 years old, firms have between 1 and 77 employees, the number of investments ranges from 0 to 21, and venture capital firms have between 1 and 95 companies in their portfolio (this information was obtained from ASCRI yearbook 2003).

\begin{tabular}{|c|c|c|c|c|}
\hline & Mean & Min. & Max. & S.D. \\
\hline Age of VC firm (in years) $(\mathrm{N}=41)$ & 9.54 & 1 & 21 & 6.61 \\
\hline Number of employees in $2003(\mathrm{~N}=41)$ & 10.54 & 1 & 77 & 12.39 \\
\hline Number of investments in $2003(\mathrm{~N}=35)$ & 6.06 & 0 & 21 & 5.67 \\
\hline Number of companies in the portfolio $(31.12 .2003)(\mathrm{N}=33)$ & 20.02 & 1 & 95 & 22.20 \\
\hline
\end{tabular}

$\mathrm{N}$ is the number of available observations for each characteristic of the venture capital firm

Table 1. Descriptive statistics on the respondents

\section{Methodology}

Since some organizations field might be more standardized than others as a result of institutional pressures within the field, we perform a discriminant analysis in order to determine whether there are any differences between venture capitalists' contractual choices depending on the venture capitalist's experience, investment strategy or the origin of the resources. The discriminant analysis is conducted because it is a technique that allows for the identification of variables that best discriminate between two or more groups in order to identify if certain groups of VCs act in a similar way. 
To carry out the discriminant analysis we use the variables that construct our hypothesis as the dependent variables, i.e. firm structure (public or private capital), development stage (the preference for early or late-stage investments) and VCs' experience or inexperience. As for the independent variables, we use the 25 covenants. We perform the analysis by stepwise inclusion method in order to minimize Wilk's Lambda in each step.

\section{Variables}

\section{Independent variables}

Using a five-point Likert scale ( $1=$ little important; $5=$ very important) the questionnaire collects information concerning the most important venture capital contractual covenants identified by previous empirical literature.

Based on previous research, we have classified the covenants into four dimensions, which allow us a better study and understanding of the venture capitalist's behaviour in designing the financial contract: 1) contractual covenants in the pre-investment relationship, 2) contractual covenants in the post investment relationship management, 3) contractual covenants in specific events in post investment period and 4) exit covenants. Out of 25 covenants, 1 belongs to the pre-investment agreements category, 17 are classified in the post-investment relationship management, 5 covenants included to control for specifics events in the post investment period, and finally 2 are exit covenants.

Table 2 shows the means and standard deviations of our independent variables by groups and ranked in descending order. The most significant contractual covenants are related to the post investment relationship management, being the most important the periodic presentation of accounting states with a mean of 5.00, followed by periodic economic-financial reports (4.95), yearly audits (4.95) and the presentation of the next budget (4.90). All these variables represent the venture capitalist's rights to be informed regarding the situation and evolution of the company. The least important covenants are those that impose limitations on contracting external advisors (2.65), that negotiate their contract's length with managers (2.93) and that control for the reliability of the information provided in the business plan (2.97).

\section{Dependent variables}

We classify firms in our sample into experienced or inexperienced using the median of the age of the VC firm, which we calculate as the number of years since the foundation of the company until 2003 (when we receipt the last questionnaire). We find a positive correlation between the most experienced VC firms and the number of total investments made since the company was founded (Cornelius \& Hargreaves, 1991; Isaksson et al., 2004). As for the origin of the resources and the investment strategy, we split our sample into public or private VCF and 
investors focused on early or late stage of development projects respectively using their own assessment given in the survey.

\begin{tabular}{|c|c|c|}
\hline & $\underset{n=37}{\substack{\text { Overall mean } \\
\mathbf{n}}}$ & $\begin{array}{l}\text { Standard } \\
\text { Deviation }\end{array}$ \\
\hline \multicolumn{3}{|l|}{ Pre Investment agreements } \\
\hline $\begin{array}{l}\text { Control for the reliability of the information provided in the business plan (due } \\
\text { diligence) }\end{array}$ & 2.97 & 1.13 \\
\hline \multicolumn{3}{|l|}{ Post Investment Relationship Management } \\
\hline Periodic presentation of accounting states & 5.00 & 0.00 \\
\hline Periodic economic-financial reports & 4.95 & 0.21 \\
\hline Yearly audits & 4.95 & 0.21 \\
\hline Presentation of the next budget & 4.90 & 0.62 \\
\hline Information about substantial matters which may affect any aspect of the business & 4.78 & 0.52 \\
\hline Right of VCs to participate in Bo D & 4.68 & 0.82 \\
\hline Veto rights of VCs on important decisions & 4.54 & 0.89 \\
\hline Veto Rights of the VCs in particular agreements & 4.32 & 1.12 \\
\hline Veto rights on new issue of shares & 4.24 & 1.20 \\
\hline Stand Still agreement & 3.85 & 1.29 \\
\hline Veto rights on executive's salary & 3.59 & 1.48 \\
\hline Limitation on important expenses are established & 3.51 & 1.41 \\
\hline Managers cannot spread the own technology & 3.51 & 1.36 \\
\hline Non-competition clause & 3.44 & 1.50 \\
\hline Limitation on the external indebtness of the company & 3.39 & 1.37 \\
\hline Limitation on loan, transfer or advance in loan to administrators & 3.34 & 1.40 \\
\hline Limitations on contracting external advisors & 2.65 & 1.35 \\
\hline \multicolumn{3}{|l|}{ Specifics Events In Post Investment Period } \\
\hline Anti-dilution ratchet & 4.48 & 0.93 \\
\hline It provides a compensation for breach of contract & 3.76 & 1.52 \\
\hline The VC Firm can to intervene if the objectives are not achieved & 3.71 & 1.23 \\
\hline VC has the power to force changes in the Bo D & 3.20 & 1.52 \\
\hline A dateline is fixed for the VCF to complain about errors or omissions & 3.05 & 1.60 \\
\hline \multicolumn{3}{|l|}{ Exit } \\
\hline Timing of exit & 3.66 & 1.27 \\
\hline Length of contract & 2.93 & 1.23 \\
\hline
\end{tabular}

Measured on five point Likert scale: 1 (I completely disagree) to 5 (I completely agree). We limit our analyses to the 37 VCF that give their scores in all the variables.

Table 2. Contractual covenants in VC

Table 3 shows that the capital is private in 30 venture capital firms $(73.17 \%)$, which are mostly inexperienced and later stage investors (25 out of the 30 firms). Among the 11 public venture capital firms, it is remarkable that there are 9 experienced organizations, probably because the beginning of this industry in Spain was trigger by government intervention. Venture capitalists in our sample show a clear preference (31 or $75.61 \%$ of the sample) by investments in late 
stages of development (post-creation or expansion financing), being 21 of them organizations with little experience. Finally, it should be highlighted that 27 organizations $(65.85 \%)$ are classified as inexperienced.

\begin{tabular}{|c|c|c|c|c|}
\hline & \multicolumn{2}{|c|}{ VC structure } & \multirow[b]{2}{*}{ Row Total } & \multirow[b]{2}{*}{ Significance } \\
\hline & Public & Private & & \\
\hline \multicolumn{5}{|c|}{ Development stage } \\
\hline Early & $5(45.46 \%)$ & $5(16.67 \%)$ & $10(24.39 \%)$ & $*$ \\
\hline Late & $6(54.54 \%)$ & $25(83.33 \%)$ & $31(75.61 \%)$ & $*$ \\
\hline \multirow[t]{3}{*}{ Column total } & $11(26.83 \%)$ & $30(73.17 \%)$ & $41(100 \%)$ & \\
\hline & \multicolumn{2}{|c|}{ VC structure } & & \\
\hline & Public & Private & Row Total & Significance \\
\hline \multicolumn{5}{|l|}{ VC experience } \\
\hline Experience & $9(81.82 \%)$ & $5(16.67 \%)$ & $14(34.15 \%)$ & $* * *$ \\
\hline Inexperience & $2(18.18 \%)$ & $25(83.33 \%)$ & $27(65.85 \%)$ & $* * *$ \\
\hline \multirow[t]{3}{*}{ Column total } & $11(26.83 \%)$ & $30(73.17 \%)$ & $41(100 \%)$ & \\
\hline & \multicolumn{2}{|c|}{ VC experience } & & \\
\hline & Experience & Inexperience & Row Total & Significance \\
\hline \multicolumn{5}{|c|}{ Development stage } \\
\hline Early & $4(28.57 \%)$ & $6(22.22 \%)$ & $10(24.39 \%)$ & \\
\hline Late & $10(71.43 \%)$ & $21(77.78 \%)$ & $31(75.61 \%)$ & \\
\hline Column total & $14(34.15 \%)$ & $27(65.85 \%)$ & $41(100 \%)$ & \\
\hline
\end{tabular}

Statistical significance at the $10 \%, 1 \%$ level is indicated by $*, * * *$, respectively

Table 3. Venture capital fund characteristics

\section{Results}

\section{Description of covenants}

For each VCF we reclassify our independent variables in a new scale consisting in three levels. Variables that take on the values 1 and 2 have been classified as seldom used, those covenants that score 3 are classified as sometimes used, and finally variables that take on the values 4 and 5 are classified as almost always used.

Next, each term is classified as rare, situational or standard. When a term is seldom used by over $80 \%$ of the respondents, it is called rare. When a term is almost always used by over $80 \%$ of the respondents, it is called standard. The $80 \%$ cut-off is selected following the scheme proposed by Isaksson et al. (2004). Finally, covenants that can't be classified as either standard or rare are classified as situational. In table 4 we observe that 9 covenants ( $36 \%$ of the covenants used by VCs in our sample) are classified as standard, whereas 16 $(64 \%)$ are situational covenants used to deal with specific contexts. No covenants are rare (further detail of covenants included in each category can be found in Appendix C). These 
results suggest the existence of some heterogeneity in the design of contracts through the inclusion of the so call "situational covenants".

\begin{tabular}{|l|c|c|}
\hline \multicolumn{1}{|c|}{ Type of term } & Frequency & \% \\
\hline Number of rare & 0 & 0 \\
\hline Number of situational & 16 & 64 \\
\hline Number of standard & 9 & 36 \\
\hline Sum & 25 & 100 \\
\hline
\end{tabular}

Table 4. Summary of rare, situational and standard covenants

\section{Differentiating strategies}

Although the above analyses confirm that venture capital contracts are mostly standardized, our results also show the existence of some degree of heterogeneity. Therefore, in this section we want to assess the origin of those differences in the design of the contracts.

We use a discriminant analysis in order to determine whether there are any differences between venture capitalists' contractual choices depending on their experience, investment strategy and fund structure. We carry out the discriminant analysis using the firm structure (public or private capital), the investment strategy (the preference for early or late stage investments) and VCs' experience or inexperience as dependent variables. As independent variables we use the 25 covenants included in the survey. The analysis is performed by stepwise inclusion method in order to minimize Wilk's Lambda in each step, resulting in a $100 \%$ of correctly classified observations.

As we can see in table 5, most of covenants do not discriminate between venture capital firms grouped according to their experience (91.67\%) or investment preferences $(83.33 \%)$, suggesting that normative and mimetic pressures drive financial contracts towards standardization. However, 11 out of the 24 contractual covenants (45.83\%) discriminate between public and private venture capital firms. Opposite to the results provided by Isaksson et al. (2004), investment preferences do not seem to influence the design of contracts for venture capital firms in our sample. Results regarding the experienced and venture capital structure are in line with those presented by Isaksson et al. (2004).

\begin{tabular}{|l|c|c|c|c|c|c|}
\hline & \multicolumn{2}{|c|}{ Experience } & \multicolumn{2}{c|}{$\begin{array}{c}\text { Investment } \\
\text { Preference }\end{array}$} & \multicolumn{2}{c|}{ Firm structure } \\
\hline & No. & $\%$ & No. & $\%$ & No. & $\%$ \\
\hline Variables that do not discriminate & 22 & 91.67 & 20 & 83.33 & 13 & 54.17 \\
\hline Variables that discriminate & 2 & 8.33 & 4 & 16.67 & 11 & 45.83 \\
\hline
\end{tabular}

The variable "Periodic presentation of accounting states" has been omitted from this analysis because it always takes on the value 5 .

Table 5. Discriminant analysis on the three dependent variables 
In table 6 , we observe that those 2 contractual covenants discriminating between experienced and inexperience firms are related with the situational loyalty clauses in the 'post investment relationship management' (non-competition clause and not spread the own technology). In addition, the non-competition clause is situational for the experienced VCs and standard for the inexperienced ones.

\begin{tabular}{|l|c|c|c|c|c|c|}
\hline & \multicolumn{3}{|c|}{ Experienced } & \multicolumn{3}{c|}{ Inexperienced } \\
\hline & Rare & Situat. & Stand. & Rare & Situat. & Stand. \\
\hline Post Investment Relationship Management & $\mathrm{x}$ & & & & $\mathrm{x}$ \\
\hline Non-competition clause & $\mathrm{x}$ & & & $\mathrm{x}$ & \\
\hline $\begin{array}{l}\text { Managers cannot spread } \\
\text { the own technology }\end{array}$ & & & & \\
\hline
\end{tabular}

Table 6. Analysis of rare, situational and standard covenants for experienced and inexperienced VCs

Table 7 shows that among VCF preferring early stage investments, only $25 \%$ of the covenants are standard, while for those that prefer to invest in late stages $50 \%$ correspond to standard covenants. The main difference between the two groups is the veto rights that the venture capitalists have in particular agreements, which is situational for early stages and standard for later stages. Due to the high level of risk and uncertainty, the high risk of failure and the lack of a strong legal system surrounding the early stage investments, VCs depend on previous experience in selecting new ventures (Elango, Fried, Hisrich \& Polonchek, 1995; Ruhnka \& Young, 1987, 1991; Klausner \& Litvak, 2001; Hyytinen \& Toivanen, 2003; Bruton et al., 2005). Therefore, when VCs make an investment in early stages of development, they tend to rely on their previous experience or they try to mimic the contractual arrangements of late stage investments.

\begin{tabular}{|l|c|c|c|c|c|c|}
\hline & \multicolumn{3}{|c|}{ Early } & \multicolumn{3}{c|}{ Late } \\
\hline & Rare & Situat. & Stand. & Rare & Situat. & Stand. \\
\hline Post Investment Relationship Management & $\mathrm{x}$ & & & & \\
\hline $\begin{array}{l}\text { Veto Rights of the VCs in } \\
\text { particular agreements }\end{array}$ & & $\mathrm{x}$ & & & $\mathrm{x}$ \\
\hline $\begin{array}{l}\text { Presentation of the next } \\
\text { budget }\end{array}$ & & $\mathrm{x}$ & & & & \\
\hline $\begin{array}{l}\text { A dateline is fixed for the } \\
\text { firm to complain about } \\
\text { errors or omissions }\end{array}$ & & & & & \\
\hline Exit & & $\mathrm{x}$ & & & $\mathrm{x}$ & \\
\hline Length of contract & & & & \\
\hline
\end{tabular}

Table 7. Analysis of rare, special and standard covenants for early and late VCs

Finally, public vs. private venture firms' contractual choices are assessed (firm structure) in table 8 . Among public $\mathrm{VCF}, 36.36 \%$ of the covenants are rare, while for the private ones 
$36.36 \%$ correspond to standard covenants. A rare covenant for the subsample of public venture capital firms means that there are "seldom used" covenants used by more than $80 \%$ of public firms. The main differences between the two groups are the right of VCs to participate in the board of directors, the obligation of the firm to provide information about substantial matters which may affect any aspect of the business, which are situational for public VCF and standard for the private ones. The non-competition clause is rare for public firms and standard for the private ones. Moreover, the power of the VCs to force changes in the board of directors, the penalties for breach the contract, or the dateline for the VCF to complain about errors or omissions are rare for public VCF and situational for the private ones.

\begin{tabular}{|c|c|c|c|c|c|c|}
\hline & \multicolumn{3}{|c|}{ Public } & \multicolumn{3}{|c|}{ Private } \\
\hline & Rare & Situat. & Stand. & Rare & Situat. & Stand. \\
\hline \multicolumn{7}{|l|}{ Pre Investment agreements } \\
\hline $\begin{array}{l}\text { Control for the reliability of the } \\
\text { information provided in the business } \\
\text { plan (due diligence) }\end{array}$ & & $\mathrm{x}$ & & & $x$ & \\
\hline \multicolumn{7}{|c|}{ Post Investment Relationship Management } \\
\hline Right of VCs to participate in Bo D & & $x$ & & & & $x$ \\
\hline $\begin{array}{l}\text { Limitation on loan, transfer or advance } \\
\text { in loan to administrators }\end{array}$ & & $\mathrm{x}$ & & & $\mathrm{x}$ & \\
\hline Non-competition clause & $x$ & & & & & $x$ \\
\hline $\begin{array}{c}\text { Managers cannot spread the own } \\
\text { technology }\end{array}$ & & $\mathrm{x}$ & & & $\mathrm{x}$ & \\
\hline $\begin{array}{c}\text { Information about substantial matters } \\
\text { which may affect any aspect of the } \\
\text { business }\end{array}$ & & $\mathrm{x}$ & & & & $\mathrm{x}$ \\
\hline Presentation of the next budget & & & $x$ & & & $x$ \\
\hline $\begin{array}{c}\text { VC has the power to force changes in } \\
\text { the Bo } D\end{array}$ & $x$ & & & & $\mathrm{x}$ & \\
\hline $\begin{array}{l}\text { It provides a compensation for breach } \\
\text { of contract }\end{array}$ & $x$ & & & & $x$ & \\
\hline $\begin{array}{l}\text { A dateline is fixed for the VCF to } \\
\text { complain about errors or omissions }\end{array}$ & $x$ & & & & $x$ & \\
\hline \multicolumn{7}{|l|}{ Exit } \\
\hline Length of contract & & $x$ & & & $x$ & \\
\hline
\end{tabular}

Table 8. Analysis of rare, special and standard covenants for public and private VCs

According to our hypothesis, and the results provided by Isaksson et al. (2004), coercive isomorphic pressures seem to originate the heterogeneity we observe between the covenants included in the financial contract by public and private VCF. The consequence of these differences is that private venture capital companies are stricter in the application of covenants. 


\section{Discussion and conclusion}

On the basis of the Institutional Theory, the central inquiry of this paper is to provide new evidence on the Spanish venture capital industry. The study is conducted by means of a survey answered by 41 Spanish venture capital firms which supply information regarding contractual arrangements used in their relationship with their portfolio companies.

In line with the findings of Isaksson et al. (2004) in Sweden, this analysis shows that a large part of the Spanish venture capital contracts are quite similar. It shows a high level of industry standardization. In this study, this is particularly obvious when we study the venture capital firms according to some characteristics, such as VCs' experience or investment preferences. However, some differences in the design of contracts between public and private venture capital firms appear due to a lower degree of isomorphism within the group of public companies. This is the result of the coercive pressures exerted by the government on them, making their behavior heterogeneous not only in relation to the industry but also within the field.

The main difference with respect to the Swedish VC contractual arrangements (Isaksson et al., 2004) is that the investment preferences have no effect on the design of contracts for the Spanish venture capital firms. However, for the Swedish case, the two groups of firms (early or later stage investors) operate in different institutional environment and, as a consequence, can be seen as two different organizational fields within the industry.

Our results contribute to shed light on the financial contracts used by venture capitalists, a field of research that has so far received little discussion in the Spanish literature. Furthermore, this paper has clear benefits for policy makers, firms, and venture capitalists. A better understanding of covenants included in venture capital contracts can help firms to understand the particular terms and restraints of VCs before providing capital. Venture capitalists can use the information from this study to better understand the contractual arrangements use in their fields. And policy makers will acknowledge the effect that their pressures have on the design of venture capital contracts and, therefore, on the efficiency of the industry when providing funds to firms.

There is however one note of caution with regard to our results. Qualitative information about venture capital firms is difficult to obtain and often has to come from survey data, like in our sample. We recognize that survey data might create potential biases and possible measurement problems (Zacharakis \& Meyer, 1998). However, we consider that our sample has large enough coverage of the venture capital industry $(68.33 \%)$ that, although cautiously, valid conclusions can be drawn. 
Further studies could expand the scope of this research to include new variables which may affect the VC contract, such as the location of the firm or gender of the VCs from an institutional perspective.

\section{Acknowledgment}

The authors acknowledge financial support by Fundación Séneca (Project 15403/PHCS/10), and by Ministerio de Ciencia e Innovación (Project ECO2011-29080).

\section{References}

ANUARIO ASCRI 2003 (Asociación Española de Entidades de Capital Riesgo).

BRANDER, J.; EGAN, E.; HELLMANN, T. (2009). Government Sponsored versus Private Venture Capital: Canadian Evidence. In Lerner, J. and Shoar, A. (ed.) International Differences in Entrepreneurship. University of Chicago Press.

BRUTON, G.D.; FRIED, V.H.; MANIGART, S. (2005). Institutional Influences on the Worldwide Expansion of Venture Capital. Entrepreneurship: Theory and Practice, 29(6): 737-760. http://dx.doi.org/10.1111/j.1540-6520.2005.00106.x

BRUTON, G.D.; AHLSTROM, D.; HAN-LIN, L. (2010). Institutional Theory and Entrepreneurship: Where are we now and where do we need to move in the future? Entrepreneurship: Theory and Practice, 34: 421-440. http://dx.doi.org/10.1111/j.15406520.2010.00390.x

CORNELIUS, B.; HARGREAVES, C. (1991). The Role of Covenants in Venture Capital Investment Agreements. Working paper. University of New England.

CORNELIUS, B. (2005). The institutionalisation of venture capital. Technovation, 25(6): 599-608. http://dx.doi.org/10.1016/j.technovation.2003.12.001

CUMMING, D.J.; MACINTOSH, J. (2006). Crowding Out Private Equity: Canadian Evidence. Journal of Business Venturing, 21: 569-609. http://dx.doi.org/10.2139/ssrn.323821

DEL-PALACIO, I.; ZHANG, X.T.; SOLE, F. (2012). The capital gap for small technology companies: Public venture capital to the rescue? Small Business Economics, 38(3): 283301. http://dx.doi.org/10.1007/s11187-010-9275-6

DIMAGGIO, P.J.; POWELL, W.W. (1983). The iron cage revisited: institutional isomorphism and collective rationality in organizational fields. American Sociological Review, 48(2): 147-160. http://dx.doi.org/10.2307/2095101

DIMAGGIO, P. (2001). Conclusion: The futures of business organization and paradoxes of change. In P. DiMaggio (ed.). The twenty-first century firm, 210-243. Princeton: Princeton University Press. 
DOH, J.P.; GUAY, T.R. (2006). Corporate Social Responsibility, Public Policy, and NGO Activism in Europe and the United States: An Institutional-Stakeholder Perspective. Journal of Management Studies, 43(1): 47-73. http://dx.doi.org/10.1111/j.1467-6486.2006.00582.x

ELANGO, B.; FRIED, V.; HISRICH, R.; POLONCHEK, A. (1995). How Venture Capital Firms Differ. Journal of Business Venturing, 10(2): 157-179. http://dx.doi.org/10.1016/08839026(94)00019-Q

FRUMKIN, P.; GELASKIEWICZ, J. (2004). Institutional Isomorphism and Public Sector Organizations. Journal of Public Administration Research and Theory, 14(3): 283-307. http://dx.doi.org/10.1093/jopart/muh028

HOFFMAN, A.J. (1999). Institutional evolution and change: Environmentalism and the US chemical industry. Academy of Management Journal, 42: 351-371. Available at: http://links.jstor.org/sici?sici=0001-4273\%28199908\%2942\%3A4\%3C351\%3AIEACEA \%3E2.0.CO\%3B2-9 http://dx.doi.org/10.2307/257008

HYYTINEN, A.; TOIVANEN, O. (2003). Asymmetric Information and the Market Structure of the Venture Capital Industry. Journal of Financial Services Research, 23(3): 241-249. http://dx.doi.org/10.1023/A:1024623729622

ISAKSSON, A.; CORNELIUS, B.; LANDSTRÖM, H.; JUNGHAGEN, S. (2004). Institutional theory and contracting in venture capital: the Swedish experience. Venture Capital, 6(1): 47-71. http://dx.doi.org/10.1080/1369106042000175582

JENG, L.A.; WELLS, P.C. (2000). The determinants of venture capital funding: evidence across countries. Journal of Corporate Finance, 6: 241-289. http://dx.doi.org/10.2139/ssrn.103948

JOG, V.; LAWSON, W.; RIDING, A. (1991). The Venture Capitalist/Entrepreneur Interface: Expectations, Conflicts and Contracts. Journal of Small Business and Entrepreneurship, 8(2): 5-20.

KLAUSNER, M.; LITVAK, K. (2001). What Economists have taught us about Venture Capital Contracting. Working Paper, Stanford Law School. http://dx.doi.org/10.2139/ssrn.280024

MUNARI, F.; TOSCHI, L. (2010). Assessing the impact of public venture capital programmes in the United Kingdom: do regional characteristics matter? European Financial Management Symposium. http://dx.doi.org/10.2139/ssrn.1539384

NORTH, D.C. (1990). Institutions, Institutional Change and Economic Performance. New York: Cambridge University Press. http://dx.doi.org/10.1017/СBO9780511808678

RUHNKA, J.C.; YOUNG, J.E. (1987). A venture capital model of the development process for new ventures. Journal of Business Venturing, 2: 167-184. http://dx.doi.org/10.1016/08839026(87)90006-1 
RUHNKA, J.C.; YOUNG, J.E. (1991). Some hypotheses about risk in venture capital investing. Journal of Business Venturing, 6(2): 115-133. http://dx.doi.org/10.1016/0883-9026(91)90014-5

SCOTT, W.R. (1995). Institutions and Organizations. Thousand Oaks: Sage Publications.

SUCHMAN, M.C. (1995). Localism and globalism in institutional analysis: the emergence of contractual norms in venture finance. In Scott, W. and Christensen, S., The Institutional Construction of Organizations. Thousand Oaks: Sage Publications.

TYKVOVÁ, T. (2007). What do economists tell us about Venture capital contracts? Journal of Economic Surveys, 21(1), 65-89. http://dx.doi.org/10.1111/j.1467-6419.2007.00272.x

ZACHARAKIS, A.; MEYER, G. (1998). A lack of insight: do venture capitalists really understand their own decision process? Journal of Business Venturing, 13: 57-76. http://dx.doi.org/10.1016/S0883-9026(97)00004-9

\section{Appendix A}

List of VC firms for categorization (see methodology)

\begin{tabular}{|c|c|c|c|c|c|c|}
\hline VC code & Created & $\begin{array}{c}\text { No. } \\
\text { investments } \\
2003\end{array}$ & $\begin{array}{c}\text { No. } \\
\text { employees }\end{array}$ & $\begin{array}{c}\text { Firm } \\
\text { structure }\end{array}$ & $\begin{array}{l}\text { Experience } \\
\text { group }\end{array}$ & $\begin{array}{l}\text { Investment } \\
\text { preferences }\end{array}$ \\
\hline VCF 1 & 1999 & 0 & 11 & private & inex & late \\
\hline VCF 2 & 1988 & 12 & 60 & public & exp & early \\
\hline VCF 3 & 1997 & 2 & 6 & private & inex & late \\
\hline VCF 4 & 2000 & 1 & 8 & private & inex & late \\
\hline VCF 5 & 1991 & . & 73 & private & $\exp$ & late \\
\hline VCF 6 & 1989 & 16 & 9 & public & $\exp$ & early \\
\hline VCF 7 & 2000 & . & 1 & private & inex & late \\
\hline VCF 8 & 1992 & 1 & . & public & inex & early \\
\hline VCF 9 & 1986 & 4 & 12 & private & exp & late \\
\hline VCF 10 & 1984 & 3 & 6 & public & $\exp$ & early \\
\hline VCF 11 & 1988 & . & 3 & private & exp & late \\
\hline VCF 12 & 2000 & . & 1 & private & inex & late \\
\hline VCF 13 & 1987 & . & 4 & private & inex & late \\
\hline VCF 14 & 2000 & 3 & . & private & inex & late \\
\hline VCF 15 & 2001 & 3 & 4 & private & inex & early \\
\hline VCF 16 & 1990 & 2 & 1 & private & inex & late \\
\hline VCF 17 & 1999 & . & 4 & private & inex & early \\
\hline VCF 18 & 1992 & 0 & 7 & private & inex & late \\
\hline VCF 19 & 2000 & 4 & 12 & private & inex & late \\
\hline VCF 20 & 1999 & 4 & . & private & inex & early \\
\hline VCF 21 & 2000 & 2 & 3 & private & inex & late \\
\hline VCF 22 & 2000 & 1 & 8 & private & inex & late \\
\hline VCF 23 & 1982 & 11 & 8 & private & $\exp$ & late \\
\hline VCF 24 & 1999 & 0 & 19 & private & inex & late \\
\hline
\end{tabular}




\begin{tabular}{|c|c|c|c|c|c|c|}
\hline VC code & Created & $\begin{array}{c}\text { No. } \\
\text { investments } \\
\mathbf{2 0 0 3}\end{array}$ & $\begin{array}{c}\text { No. } \\
\text { employees }\end{array}$ & $\begin{array}{c}\text { Firm } \\
\text { structure }\end{array}$ & $\begin{array}{c}\text { Experience } \\
\text { group }\end{array}$ & $\begin{array}{c}\text { Investment } \\
\text { preferences }\end{array}$ \\
\hline VCF 25 & 1999 & 3 & 2 & private & inex & early \\
\hline VCF 26 & 2000 & 2 & - & private & inex & late \\
\hline VCF 27 & 1984 & 11 & 14 & public & exp & late \\
\hline VCF 28 & 1984 & 6 & 8 & public & exp & late \\
\hline VCF 29 & 2000 & 13 & 5 & private & inex & late \\
\hline VCF 30 & 1993 & 0 & 8 & private & inex & late \\
\hline VCF 31 & 1993 & 5 & 3 & public & inex & late \\
\hline VCF 32 & 1989 & 7 & 2 & private & inex & late \\
\hline VCF 33 & 1986 & 2 & 4 & private & inex & late \\
\hline VCF 34 & 2001 & 8 &. & private & inex & late \\
\hline VCF 35 & 1998 & 5 & 5 & private & inex & late \\
\hline VCF 36 & 2002 & 11 & 7 & private & inex & late \\
\hline VCF 37 & 1987 & 6 & 16 & private & Exp & late \\
\hline
\end{tabular}

The Number of investments is the total number of investments made since VC firm was established

\section{Appendix B}

\section{List of covenants in contracts}

\section{Pre-investment agreements}

Control for the reliability of the information provided in the business plan (due diligence)

\section{Post-investment relationship management}

Limitations on contracting external advisors

Right of VCs to participate in Bo D

\section{Entrepreneur should refrain from} transactions with intimates

VCs to requests one or several places in the investee's Board of Directives

\section{Veto rights of VCs on...}

New issue of shares

Limitations are put on purchase, subscription and sale of any company's shares

Executive's salary

Important decisions Limitation on executive's salary

The Firm has the right of veto on some decisions

\section{Financial Limitations}

Limitation on important expenses are established

Limitation on the external indebtness of the company

Limitation on loan, transfer or advance in loan to administrators

\begin{tabular}{|l|l|}
\hline \multicolumn{2}{|c|}{ Loyalty clause } \\
\hline Non-compete clause & Non-competition clause is negotiated with managers \\
\hline Managers cannot spread the own technology & Managers are obliged not to spread the own technology \\
\hline \multicolumn{1}{|c|}{ Informational requirements } \\
\hline Periodic presentation of accounting states & $\begin{array}{l}\text { Periodic presentation of accounting states: Balance and } \\
\text { profit and loss account }\end{array}$ \\
\hline Periodic economic-financial reports & \\
\hline Yearly audits & The Firm has to present the budget for the next year, at \\
\hline Presentation of the next budget &
\end{tabular}




\begin{tabular}{|c|c|}
\hline & the end of the financial year \\
\hline \multicolumn{2}{|c|}{$\begin{array}{l}\text { Information about substantial matters which may affect } \\
\text { any aspect of the business }\end{array}$} \\
\hline Veto Rights of the VCs in particular agreements & $\begin{array}{l}\text { A clause is fixed which requires a favourable vote in } \\
\text { particular agreements from the Firm's Advisors of the } \\
\text { Venture Capital }\end{array}$ \\
\hline Stand Still agreement & The manager is not allowed to sell equity \\
\hline \multicolumn{2}{|c|}{ Specifics events in post-investment period } \\
\hline VC has the power to force changes in the Bo $D$ & $\begin{array}{l}\text { The venture capital firm leaves open the possibility to } \\
\text { force changes in the investee's board of directors }\end{array}$ \\
\hline \multicolumn{2}{|c|}{$\begin{array}{l}\text { The VC Firm can to intervene if the objectives are not } \\
\text { achieved }\end{array}$} \\
\hline \multicolumn{2}{|l|}{ It provides a compensation for breach of contract } \\
\hline Anti-dilution ratchet & $\begin{array}{l}\text { If the capital is increased, the venture capital firm has } \\
\text { the right of preferential subscription in order to ensure it } \\
\text { ownership of the company's security }\end{array}$ \\
\hline \multicolumn{2}{|c|}{$\begin{array}{l}\text { A dateline is fixed for the firm to complain about errors } \\
\text { or omissions }\end{array}$} \\
\hline \multicolumn{2}{|c|}{ Exit } \\
\hline Timing of exit & $\begin{array}{l}\text { The Firm leaves open the possible temporal reduction of } \\
\text { its permanence in the investee }\end{array}$ \\
\hline Length of contract & Contract's length is negotiated with managers \\
\hline
\end{tabular}

\section{Appendix C}

Analysis of rare, situational and standard covenants

\begin{tabular}{|c|c|c|c|}
\hline & Rare & Situational & Standard \\
\hline \multicolumn{4}{|l|}{ Pre-investment agreements } \\
\hline $\begin{array}{l}\text { Control for the reliability of the information provided in the business plan } \\
\text { (due diligence) }\end{array}$ & & $x$ & \\
\hline \multicolumn{4}{|l|}{ Post-investment relationship management } \\
\hline Limitations on contracting external advisors & & $x$ & \\
\hline Right of VCs to participate in Bo D & & & $x$ \\
\hline \multicolumn{4}{|l|}{ Veto rights of VCs on... } \\
\hline New issue of shares & & & $\mathrm{x}$ \\
\hline Executive's salary & & $\mathrm{x}$ & \\
\hline Important decisions & & & $\mathrm{x}$ \\
\hline \multicolumn{4}{|l|}{ Financial Limitations } \\
\hline Limitation on important expenses are established & & $\mathrm{x}$ & \\
\hline Limitation on the external indebtness of the company & & $\mathrm{x}$ & \\
\hline Limitation on loan, transfer or advance in loan to administrators & & $\mathrm{x}$ & \\
\hline \multicolumn{4}{|l|}{ Loyalty clause } \\
\hline Non-compete clause & & $\mathrm{x}$ & \\
\hline Managers cannot spread the own technology & & $\mathrm{x}$ & \\
\hline \multicolumn{4}{|l|}{ Informational requirements } \\
\hline Periodic presentation of accounting states & & & $x$ \\
\hline Periodic economic-financial reports & & & $x$ \\
\hline Yearly audits & & & $x$ \\
\hline Presentation of the next budget & & & $x$ \\
\hline $\begin{array}{l}\text { Information about substantial matters which may affect any aspect of the } \\
\text { business }\end{array}$ & & & $x$ \\
\hline
\end{tabular}




\begin{tabular}{|c|c|c|}
\hline Veto Rights of the VCs in particular agreements & & $x$ \\
\hline Stand Still agreement & $\mathrm{x}$ & \\
\hline \multicolumn{3}{|l|}{ Specifics events in post-investment period } \\
\hline VC has the power to force changes in the Bo D & $x$ & \\
\hline The VC Firm can to intervene if the objectives are not achieved & $x$ & \\
\hline It provides a compensation for breach of contract & $x$ & \\
\hline Anti-dilution ratchet & $x$ & \\
\hline A dateline is fixed for the firm to complain about errors or omissions & $x$ & \\
\hline \multicolumn{3}{|l|}{ Exit } \\
\hline Timing of exit & $x$ & \\
\hline Length of contract & $x$ & \\
\hline
\end{tabular}

C Intangible Capital, 2013 (www.intangiblecapital.org)

El artículo está con Reconocimiento-NoComercial 3.0 de Creative Commons. Puede copiarlo, distribuirlo y comunicarlo públicamente siempre que cite a su autor y a Intangible Capital. No lo utilice para fines comerciales. La licencia completa se puede consultar en http://creativecommons.org/licenses/by-nc/3.0/es/ 